\title{
A HELYI TERMÉKEK JELENTŐSÉGE A VIDÉKGAZDASÁGBAN
}

\author{
Dr. Ph.D. Panyor Ágota \\ egyetemi docens, Szegedi Tudományegyetem Mérnöki Kar, Szeged
}

\section{SUMMARY}

As we experienced nowadays, the accelrating changes of the unpredictable profitability of the economy, the changing agrar policy, the problems caused by the intensive agriculture and the climate change are threatening the viability and the health of the natural enviroment and the population. These changes can not be left ignored. The aim of my thesis, to demonstrate, one of the effective instruments of the reduction of vulnerability is the creation and maintenance of diverse local economy. I point tot the local products and the local consumption can be the sustaninig force of the rural population, and to those opportunities which enable a more liveable enviroment.

\section{BEVEZETÉS}

A mezőgazdaság, illetve a vidéki térségekben megvalósuló élelmiszertermelés létünk alapja, talán mégsem kezeljük ehhez képest méltóan. A mezőgazdasági gazdálkodás munkát, élelmet, megélhetést biztosít az emberek számára. A termelési feladatok mellett regionálisan eltérö környezeti és társadalmi, foglalkoztatási feladatokat is magára kell vállalnia.

Egyre fontosabbá válik, hogy a gazdálkodók új utakat keressenek, amely enyhíti függőségüket a számukra befolyásolhatatlan piactól, az energia- és termékellátástól. Önellátásra törekvö helyi gazdasági rendszer kialakítására kell törekedniük a gazdálkodóknak, melynek fontos mozgatórugója a helyi termékek és az azokkal kapcsolatos fejlesztési lehetőségek (Székelyhidi, 2003). A helyi termékek feltérképezésének és fejlesztésének szükségességét tehát, a helyi társadalmi-gazdasági rendszer kialakításának igénye, illetve az ilyen alapokra helyezkedő rendszer irányába történő elmozdulás alapozza meg. Munkámban szeretnék rámutatni arra, hogy a helyi termékek és a helyi fogyasztás a vidék lakosságmegtartó ereje lehet, valamint azon lehetőségekre, melyek segítségével egy élhetőbb vidék alakítható $\mathrm{ki}$.

\section{A KISTERMELŐI RENDELET VÁLTOZÁSA}

2010. május 15-én lépett hatályba a 52/2010 (IV.30.) FVM rendelet - Kistermelöi rendelet - módosítása számos lobbizás és a sok civil szervezet ajánlásának megfelelöen. A módosításra azért volt szükség, mert az Uniós csatlakozás és a közösségi szabályozások életbe lépése nehéz helyzetbe hozta a kistermelöket, akik nem voltak felkészülve a nemzetközi gazdaságok versenyére. A rendelet célja elsősorban a kistermelők szükös értékesitési lehetőségeinek bővítése. A módosítások olyan különbségeket rejtenek, melyekkel vidéken tömegek számára válik egyszerübbé a hozzáférés a helyi, háztáji termelésböl származó pluszjövedelemhez. A rendelet nagy lépést jelent a kistermelöi élelmiszertermelés elterjedése útján. Az új rendelet alapot szolgáltat arra, hogy a jövöben a magyar kistermelöi élelmiszerek is megtalálhatóak legyenek a boltok polcain és a vendéglátóegységek asztalain.

A módosított rendelet szerint: „A kistermelő olyan személy, aki a megtermeltbegyüjtött árut, vagy a megtermelt alaptermékböl készitett élelmiszert, jogszerüen kifogott halat egyenesen a végfogyasztónak vagy a vendéglátónak adja el. Az alaptermék és az élelmiszer fázisa között elvégeztethet harmadik féllel is köztes részfolyamatot, de csak biztosított nyomon követhetőség mellett. Az élelmiszerbiztonsági felelösség a kistermelöt terheli. Nem állati eredetü alaptermékeket, mézet és halat piacon szabadon árulhat. Minden más terméket is szabadon árulhat, de ezeket csak a termelés helyszínének helyt adó 
megyében, vagy az azzal szomszédos megyék határain belül teheti. A kecske, juh, szarvasmarha és strucc húsát csak közvágóhídi vágás után, saját gazdaságában, otthonában értékesítheti, vagy eladhatja helyi vendéglátónak, kiskereskedőnek. Az értékesitést saját maga vagy csak közeli hozzátartozója végezheti. Lényeges változás még, hogy a nagyipari feldolgozáson átesett kistermelői termék kistermelöi terméknek minősülhet a feldolgozás után is. A szükséges állategészségügyi, higiéniai szabályoknak való megfelelés, a megfelelö csomagolás, és azon a „termelöi” termékekre vonatkozó információk feltüntetése kötelezö” (52/2010. (IV.30.) FVM rendelet).

Az 52/2010. (IV.30.) FVM rendeletbe a civil szervezetek javaslatai közül számos bekerült, mely a kistermelök számára kedvezö változásokat hozott. További lényeges változásokat hozott a 2010. július 5-én hatályba lépett 4/2010 (VII.5.) VM rendelet, mely módosította a kistermelöi élelmiszer-előállításra és kereskedelemre vonatkozó korábbi elöírásokat és a civil javaslatok közül még több kedvezőt beemelt a szabályozásba.

A kistermelöi rendelet legfontosabb módosításai - a 4/2010 (VII.5.) VM rendelet szerint - a következök:

- Az állati alaptermékek és a feldolgozott kistermelöi termékek értékesíthetőek az elöállítás szerinti megyében és Budapesten (régióban), vagy gazdaság helyétől légvonalban számitva az ország területén legfeljebb $40 \mathrm{~km}$ távolságon belül a végső fogyasztó részére, valamint boltokba és vendéglátó egységekbe, így a közétkeztetésbe is.

- A kistermelő is végezhet szolgáltatásokat más magánszemély, kistermelö részére élelmiszerének elöállítása során (pl.: hús füstölés, terménytisztítás, pasztörizálás).

- Ellenörzött állományból származó baromfi és nyúlféle házi vágása esetében a településen, a végső fogyasztó számára történő értékesítésnél nem kell a vágásnál hatósági húsvizsgálatot elvégeztetni legfeljebb heti $50 \mathrm{db}$ házi tyúkféle, $25 \mathrm{db}$ vízi számyas vagy pulyka, 13 db nyúlféle vágása esetén.

- Kistermelö is végezhet falusi vendégasztal szolgáltatói tevékenységet az általa megtermelt vagy előállított, és kiegészítő alapanyagként vásárolt élelmiszer felhasználásával.

\section{A KÖZVETLEN ÉRTÉKESÍTÉS LEHETŐSÉGEI}

A kistermelök nagy része kisebb boltokba, szaküzletekbe szállít, piacon árul és az idegenforgalom révén tud értékesíteni. Az alábbiakban felsorolt - a termelö és a fogyasztó szorosabb illetve lazább kapcsolatán alapuló közvetlen kereskedelmi - módszerek olyanok, ahol a közvetítöket részben vagy egészben kiiktatják, ezzel a haszon nagyobb része marad a termelönél vagy a szövetkezésnél. A közvetlen kereskedelem lényege a termelö és a fogyasztó közvetlen kapcsolata, a bizalom, a jó minöségü, egészséges, környezetkímélő módon elöállitott áru és a tisztességes jövedelem a gazda számára. A vevők körét a helyi közösség tagjai, a városi fogyasztók és a turisták/vendégek alkotják. A közvetlen kereskedelem értékesítési formái közül a termékek értékesítésének legolcsóbb módja a helyben történő ćrtékesítés személyes eladással: helyi piacok, vásárok, saját gazdaság (Kajner 2009). 


\title{
3.1. KÖZVETLEN KERESKEDELEM FALU-VÁROS KAPCSOLATÁBAN
}

\author{
A.) Termelö és fogyasztó szorosabb kapcsolatán alapuló közvetlen kereskedelmi \\ rendszerek:
}

- Részarányos gazdálkodás: A termelő az év elején végzett becslése alapján a szerzödött vásárlói között arányosan felosztja költségeit. A befizetett összegért cserébe a fogyasztó rendszeresen megkapja a termés arányos részét.

- Allandó vásárlók rendszere (dobozrendszer): A termelő és a fogyasztók értékesítési szövetséget hoznak létre. A vásárlók kötelezettséget vállalnak a rendszeres vásárlásra, míg a termelő arra, hogy mikor és milyen terméket szállít.

- Több család közös beszerzői kört alapit: A beszerzöi kör családjainak képviselöje adott rendszerességgel egyszerre vásárolja meg és szállítja el a számukra szükséges mennyiségü élelmiszert, majd egymást közt szétosztják az árut és a költségeket.

- Közétkeztetés: A jelenleg hatályos Közbeszerzési törvénynek köszönhetően a helyben termelt terményeket közbeszerzési eljárás nélkül vásárolhatják meg a közétkeztetést végzö intézmények bölcsödék, óvodák, iskolák, hivatalok, egészségügyi intézmények).

- Speciális minöséget igénylö fogyasztók: A szermaradványok és az adalékanyagok iránti ellenérzések egyre inkább növekednek a fogyasztókban. Ennek köszönhetöen a bioélelmiszerek magas minösége és kedvezö élettani hatásai miatt egyre szélesebb körben értékesíthetők, például bioéttermek vagy rákbetegeket gyógyító intézetek számára. A kistermelöknek célszerü rendszeres, akár szerződéses kapcsolatot kiépíteniük az ilyen típusú intézményekkel (Kajner 2009).

B.) Termelö és fogyasztó lazább kapcsolatán alapuló közvetlen kereskedelmi rendszerek:

- Kiszállitási rendszer: A termelö egy elosztási pontra vagy közvetlenül házhoz szállítja a vásárlóknak a megrendelt terméket.

- Gazdálkodók piaca: A kistermelök szövetkezete, civil szervezet vagy helyi önkormányzat által szervezett alkalomszerü vagy rendszeres árusítási lehetőség kistermelök számára.

- Termelöi bolt (tájbolt): olyan kiskereskedés, melyben az adott régió gazdáinak termékeit árusítják.

- Bioélelmiszert árusitó boltok: A gazda termékeit már létezỏ bioboltokba szállítja.

- Helyi zöldséges boltok: Napjainkban sajnos általánosságban elmondható, hogy a zöldségesek nem a helyi kistermelötöl, hanem a nagybani piacról vásárolnak. Azonban érdemes a gazdáknak az együttmüködésre hajlamos zöldséges boltokat felkeresni, és kisebb mennyiség értékesitéséröl megállapodni, ezzel is növelve saját értékesítési lehetőségeiket.

- „Szedd magad” akciók: A vásárló saját maga szedi meg a terményt és fizet annak tömege szerint.

- Mozgóbolt: A gazda kisteherautó segítségével a település, illetve annak vonzáskörzetében a forgalmas csomópontoknál (például: iskola, piac, hivatal) az autóról árulja termékeit.

- Internetes kereskedelem: Viszonylag új értékesítési lehetőség a gazdák számára. Müködő példái a Magyar Áruk Áruháza (www.hmo.hu), illetve különböző online biokereskedések (www.bionatura.hu, www.bio-bolt.hu)

- Védjegy létrehozása: A védjegyek létrehozásának célja a termelök piacra jutásának segítése. A jogtulajdonos és a védjegyfelhasználó szerződést köt. A felhasználó a szerzödésben meghatározott idöre és összegért felhasználói jogot kap. A jogtulajdonos folyamatos marketing, reklám és piacépítési feladatot lát el, egységes 
grafikai arculatot, valamint programokon, fesztivảlokon részvételi és kiállitási lehetöséget biztosit (Kajner 2009).

\subsection{KÖZVETLEN KERESKEDELEM FALUSI KÖRNYEZETBEN}

Falusi környezetben a termelök az értékesítésnél az emberek közelségére, illetve közvetlenebb kapcsolatára építhetnek. Az értékesítési módszereket - Kajner (2009) szerint megkülönböztethetjük az alapján, hogy ki a vevő.

Értékesités elsösorban helyieknek:

- helyi gazda/gazdák tájboltja a faluban,

- mozgóárusok,

- a termelö házhoz szállítja a fogyasztók megrendelését,

- a vevő házhoz jön,

- házhozszállítási rendszer, részarányos termelés vagy állandó vásárlók rendszere,

- piaci, vásári értékesítés a faluban,

- kaláka típusú élelmiszer elöállítás és feldolgozás.

Értékesités elsösorban turistáknak:

- speciális rendezvények (például: bornap, sajt- és túrófesztivál),

- értékesítés a helyi üdülők, szálláshelyek vendégei számára,

- tájjellegü éttermek, csárdák,

- nyári táborok, erdei iskolák.

\section{A HELYI TERMÉKEK SZEREPE A VIDÉK FEJLŐDÉSÉBEN}

Magyarország területének túlnyomó része vidéki jellegü. Az ott élök nagy részének az élete közvetve vagy közvetlenül kapcsolódik a mezőgazdasághoz. A vidéki térségek szempontjából ezért rendkívül fontos az agrárgazdaság jövedelmezőségének a javítása.

A közvetlen, bizalmi kapcsolatokon alapuló termelöi-fogyasztói együttmüködések, valamint a közösség által támogatott termelési formák a piaci nehézségeket diverzifikációval, az alternatív értékesítési lehetőségek kihasználásával a kistermelők túléléséhez, értékteremtéséhez, szélesebb értelemben a vidékfejlesztéshez, a fenntartható európai mezögazdálkodáshoz járulhatnak hozzá (Balázs- Simonyi, 2009).

A kistermelöknek, valamint a helyben elöállított és fogyasztott termékeknek fontos szerepe van a vidék népességmegtartó erejében. Az elmúlt időszak jelentős változásai: 52/2010 (IV.30.) FVM rendelet, a 4/2010 (VII:5.) VM rendelet és a Közbeszerzési törvény módosítása új lehetőségeket nyitott meg a kistermelök elött. A közvetlen értékesítés ereje abban rejlik, hogy a termelötől a termék közvetlenül a fogyasztóhoz jut el, kizárva a kis- és nagykereskedöket. A rövid értékesitési láncnak köszönhetően a termékek frissek, egészségesek, megbízhatók és környezetkímélök. Az adott térségre jellemzö identitás, valamint a hagyományok mellett ezen jellemzökben rejlik a helyi termékek különlegessége a tömegtermékekhez képest (Panyor, 2007). Az ilyen típusú termékek fogyasztásával nő a vidék hozzáadott értéke, valamint az ott élő gazdálkodók megélhetését is segíti.

Fontosnak tartom a helyi termékek feltérképezésének és fejlesztésének szükségességét. Ezek a termékek a vidék életében fontos szerepet töltenek be, hozzájárulnak a gazdálkodók megélhetéséhez, a vidék lakosságmegtartó erejéhez, a munkanélküliség csökkenéséhez és a vidéki életminöség javításához. Természetesen ennek alapfeltétele, hogy ne csak önmagukban létezzenek helyi termékek, hanem a fogyasztókban is tudatosodjon az, hogy a helyi termékek vásárlásával és fogyasztásával jelentös hatással lehetnek a térség gazdaságára és ebböl adódóan saját életükre. 
A Közös Agrárpolitika reformja keretében 2012 októberében az Európai Bizottság nyilvánosságra hozta az EMVA támogatásokról (2014-2020) szóló jogszabály-tervezetét. Ebben nagyon fontos szerepet kap a helyi piacok müködésének megerösítése, a helyi termékekre alapozott élelmiszer-feldolgozás, a helyben termelt különleges élelmiszerek piacra jutásának megkönnyítése, növelni kívánják a rövid értékesítési láncok szerepét. Ennek érdekében tematikus alprogramokat lehet majd a vidékfejlesztési programokba foglalni, különös tekintettel a rövid értékesítési láncokra.

\section{5. ÖSSZEFOGLALÁS}

Az elmủlt időszak törvényi változtatásainak köszönhetően ủj lehetöségek nyiltak meg a hazai kistermelök elött. Megerősödhet a helyi értékesítés, aminek köszönhetöen mindenki jól jár: a termelö, a boltos, a vendéglös és a fogyasztó is egyaránt. A termékek kiskereskedelmi és vendéglátóegységekbe történő forgalmazhatósága nagyobb jövedelemhez juttathatja a kistermelöket, fellendülhet a vidéki gazdaság és enyhülhet a válság okozta munkanélküliség. Várhatóan több különleges, minőségi magyar termék jelenik majd meg a piacon, és növekedni fog azok iránti kereslet is. Mindezzel együtt fellendülhet a turisztika és a vendéglátás is, valamint komoly változások lehetnek a hazai élelmiszer-kiskereskedelemben.

\section{IRODALOMJEGYZÉK}

Balázs B. - Simonyi B. (2009): Együtt a helyi élelmiszer-rendszerekért, Védegylet, Szövetség az Élelmiszer-önrendelkezésért, Környezeti Társadalomkutatók, Budapest

Kajner P. (2009): Helyi termelés, helyi fogyasztás, helyi termékek egészségesen!, Szövetség az Élő Tiszáért Védegylet, Budapest

Panyor Á. (2007): A földrajzi árujelzős termékek a vidékfejlesztésben. Gazdálkodás 51. évfolyam 20. Különkiadás pp. 206-208.

Székelyhidi T. (2003): Alternatív vidéki vállalkozások szervezése, Szaktudás Kiadó Ház, Budapest

52/2010. (IV.30.) FVM rendelet

4/2010. (VII.5.) VM rendelet 